\title{
DIVERSITY IN ZANONIA INDICA (CUCURBITACEAE)
}

\author{
W.J.J.O. DE WILDE \& B.E.E. DUYFJES \\ Nationaal Herbarium Nederland, Universiteit Leiden Branch, P.O. Box 9514, \\ 2300 RA Leiden, The Netherlands; e-mail: dewilde@nhn.leidenuniv.nl
}

\section{SUMMARY}

A revision of the monotypic genus Zanonia $\mathrm{L}$. is presented. The only and widely distributed species Z. indica comprises two subspecies, the typical one, and the newly described subsp. orientalis W.J. de Wilde \& Duyfjes. Subspecies orientalis also contains a distinct variety, var. paludosa W.J. de Wilde \& Duyfjes.

Key words: Cucurbitaceae, Zanonia, South East Asia.

\section{INTRODUCTION}

The monotypic genus Zanonia L. was described in 1753 without a species name; the species Zanonia indica L. dates from 1759. It was based on 'Penar-valli foemina' and 'Penar-valli mas' both in Rheede's Hortus Malabaricus (1688) 8: 91-92, t. 47-48, and 93 (“39”), t. 49, respectively. Rheede's plants originated from S India. These references were indicated as syntypes by Keraudren (1975: 18), repeated by Jeffrey (1980: 800). 'Penar-valli mas', the male plant, was chosen as the lectotype by Chakravarty (1982).

Zanonia indica was thence found elsewhere in southern, and in north-eastern India, Sri Lanka, and further in a wide area ranging from S China through Malesia east to New Guinea.

Cogniaux (1881) described the species as occurring in this wide area, and recognized two additional varieties, viz. var. pubescens, widespread, with densely hairy twigs, and var. angustifolia. The latter variety was based on sterile glabrous material with narrow leaves from Chittagong, and obviously concerned a juvenile plant. The var. pubescens was taken up later by Chakravarty (1959: 184) and was also recognized in the Flora of China (Chen, 1986) and the Flora of Yunnan (Chen, 1995). However, for China the two varieties were not distinguished on the hairiness of the twigs but on characters of the glabrous or hairy fruits and the seeds. The variety pubescens in China has larger, densely hairy fruits and larger seeds.

We examined Zanonia in a wide range in South East Asia and found that the hairiness shows up in a continuous variation in the whole area, comprising (sub)glabrous specimens to specimens with densely hairy twigs and leaves. The fruit-size is very variable as well, with fruits c. 4 by $3 \mathrm{~cm}$ (short and broad in New Guinea) to c. 9 by 3 $\mathrm{cm}$ (longer in Thailand), with intermediate sizes in specimens from localities widely dispersed in the Malesian region. Hairiness and fruit size appear not to be correlated. 
Therefore, we refrain from recognizing var. pubescens, although we have not seen the exceptionally hairy, very large-fruited material from China.

During our study we found that plants from Peninsular India and Sri Lanka have much larger male flowers than those from NE India, China and the whole area southeast to New Guinea. The two areas of the larger- and the smaller-flowered plants are geographically separated by a wide gap, the Indian Gangetic Plain. As the difference in flower size is quite apparent, we herewith propose the status of subspecies for both groups, viz. subsp. indica for the specimens from Peninsular India and Sri Lanka and subsp. orientalis for the specimens of the remaining distributional area. Deviating material from peat swamp in Borneo is here newly described as a variety (var. paludosa) under subsp. orientalis.

\section{ZANONIA}

Zanonia L. (1753) 1028; (1754) 454; Wight (1850) pl. 103; Benth. \& Hook.f. (1867) 839; C.B. Clarke (1879) 633, p.p.; Cogn. (1881) 925, excl. Z. macrocarpa = Alsomitra (Blume) M. Roem.; Cogn. (1916) 27; Chakrav. (1959) 181; Keraudren (1975) 15; Chakrav. (1982) 123. - Type: Zanonia indica $\mathrm{L}$.

Juppia Merr. (1922a) 170. - Type: Juppia borneensis Merr.

Penar-valli Adans. (1763) 139, nom. illeg., a substitute for Zanonia L.

Medium-sized liana; dioecious. Probract absent. Tendrils: (simple or) 2-branched at apex. Leaves: simple, unlobed, ovate-elliptic (-narrowly elliptic), margin entire; cystoliths absent; petiole short. Flowers: small, creamy-white; buds globose; perianth rotate; sepals 3 (but see note 1 ), concave, valvate in bud; petals 5 , free, \pm fleshy, conduplicate-valvate with tips inflexed in bud; receptacle shallow. Male inflorescences: paniculate, many-flowered, pendulous; bracts small, linear, 1(-2) mm long, glabrous or hairy. Male flowers: pedicel short; disc broad, low; stamens 5, free, inserted on the disc, filaments short, anthers all 1-thecous, opening with apical transverse slit; pistillode absent. Female flowers: in (raceme-like) panicles; pedicel very short or absent; ovary clavate, imperfectly 3-locular, each locule with apically 2 pendulous ovules; styles 3, short, horizontally 2-horned, separate, inserted on slightly raised truncate apex of ovary; staminodes absent or present (see note 2). Fruits: rather large, capsular, elongate-cylindrical, claviform, with truncate apex opening by 3 inward curving apical valves. Seeds: compressed, longitudinally winged all around the seed.

Distribution - One species with two subspecies, from India and S China, east to New Guinea.

Notes -1 . The globose calyx in bud is membranous, and closed at apex, but mostly the very apex shows 5 minute appendages proving that the calyx is morphologically 5-merous. However, at anthesis the globose bud splits into ( 2 or) 3 triangular \pm concave sepals. The five petals are thick-fleshy and drop off easily after anthesis.

2. In female flowers the staminodes are either absent (or difficult to discern), or they appear as 5 small appendages, close to the insertion of the petals. However, in the female flowers of Giesen 76 (Zanonia indica subsp. orientalis var. paludosa) the staminodes are distinctly stamen-like, each with a small anther, including an indication of the apical slit at the apex. It could not be verified whether they contain viable pollen. 


\section{Zanonia indica L.}

Zanonia indica L. (1759) 1292; (1763) 1457; Miq. (1856) 682; C.B. Clarke (1879) 633; Cogn. (1881) 926; (1916) 27; Gagnep. (1921) 1082; Chakrav. (1959) 181; Backer (1964) 295; Keraudren (1975) 16, pl. 4; S.K. Chen (1986) 129; (1995) 297; P.H. Hô (1991) 714, f. 1979; Manilal (2003) 166. - Lectotype (Chakravarty, 1982): 'Penar-valli mas' in Rheede, Hort. Malab. (1688) 8: 93 (“39"), t. 49.

For further synonyms see under subsp. orientalis.

Liana 4-15 m long; stem 3-5 mm diam., glabrous or hairy, often with lenticels, older twigs with raised leaf-scars. Tendrils: $5-15 \mathrm{~cm}$ long, in juvenile plants at apices with irregularly shaped adhesive pads to c. $5 \mathrm{~mm}$ diameter. Leaves: blade membranous or subcoriaceous, (broadly) ovate-elliptic, $8-20$ by $5-12 \mathrm{~cm}$, base broadly rounded or cordate or sometimes somewhat hastate, apex (sub)obtuse, minutely mucronate, both surfaces glabrous or hairy; 2-5-pinnately nerved and one pair of basal nerves, reticulation distinct on lower surface; petiole $1.5-3 \mathrm{~cm}$ long. Male inflorescences: glabrous or hairy, (10-)15-60 cm long, little or much branched (sometimes also branched from the base), lateral branches to $15 \mathrm{~cm}$ long, flowers often in bundles of up to 5, the bundles \pm spaced, the larger inflorescences often from the older wood. Male flowers: pedicels rather thick, 1-3(-5) mm long, articulate at \pm halfway; buds 2-4 mm diam.; sepals membranous, almost free, subtriangular, c. $2 \mathrm{~mm}$ long; petals ovate to narrowly elliptic, $2.5-3.5$ or $5-7 \mathrm{~mm}$ long, apex narrowed, subacute, adaxially papillose; stamens inserted on a carnose disc, leaving the centre free, filaments $0.5-1 \mathrm{~mm}$ long, fleshy, anthers transversely ellipsoid, (0.5-)1 mm long. Female inflorescences: $5-40 \mathrm{~cm}$ long, raceme-like or branched panicles, few- or many-flowered, flowers solitary (or 2). Female flowers: sepals triangular, 2-4 mm long; petals ovate-narrowly elliptic, 3-8 mm long, subacute, finely papillose-hairy; ovary subcylindrical-obconical, 5-12 by $2-3 \mathrm{~mm}$, glabrous or hairy; styles very short, stigmas with 2 incurved horizontal horns, papillose. Fruits: pendulous, few to many per infructescence, very variable in size, (4-)5-10 by $1.5-4.5(-5) \mathrm{cm}$, glabrous, glabrescent or hairy. Seeds: pale, elliptic, flat, not ornamented, $15(-20)$ by $8(-10) \mathrm{mm}$, winged all around, the wings leathery, much elongated and rounded at both ends, $4-6(-8)$ by $1.3-1.5(-2) \mathrm{cm}$.

Distribution - S India, Sri Lanka, NE India, S China, Indochina, through Malesia east to New Guinea. Two subspecies.

Habitat \& Ecology - Forest edges, riversides, open forest on mountain slopes; (0-)20-800 $\mathrm{m}$ altitude (recorded for Bhutan at $2300 \mathrm{~m}$ by Grierson \& Long, 1991: 269). Flowering and fruiting throughout the year.

\section{KEY TO THE SUBSPECIES}

1a. Male flowers larger; petals 4-7 mm long. - S India, Sri Lanka a. subsp. indica

b. Male flowers smaller; petals 2.5-3.5 mm long. - NE India, China, Indochina, Malesia, south-east to New Guinea . . . . . . . . . . . b. subsp. orientalis

a. subsp. indica

Plant subglabrous. Leaves: somewhat larger than in subsp. orientalis, to $20 \mathrm{~cm}$ long. Male flowers: bud c. $4 \mathrm{~mm}$ diam., open corolla c. $10 \mathrm{~mm}$ diam.; petals 4-7 mm long.

Distribution - S India, Sri Lanka. 
b. subsp. orientalis W.J. de Wilde \& Duyfjes, subsp. nov.

A subspecie typica floribus masculinis minoribus, corolla 5-7 mm diam., petalis $2.5-3.5$ mm longis differt. - Typus: Phonsena 5192 (BKF; iso L), Thailand, Chon Buri, Bo Thong, Khao Cha-ang On.

Zanonia indica L. var. pubescens Cogn. (1881) 927. - Lectotype (Chakravarty, 1982): Griffith 2521 $(\mathrm{K}$; iso $\mathrm{P})$, India, Khasia Hills.

Zanonia indica L. var. angustifolia Cogn. (1881) 927. - Type: Hook.f. \& Thomson s.n. (K; iso P), E India, Chittagong.

Tinospora curtisii Ridl. (1920) 148. - Type: Curtis 3464, male (K), Peninsular Malaysia, Penang, Batu Feringhi, near the sea.

Alsomitra simplicifolia Merr. (1922b) 470. - Type: Ramos \& Edaño BS 37397 (PNH†; iso BO, K, L, P), Philippines, Mindanao, Malangas.

Juppia borneensis Merr. (1922a) 170. - Type: Ramos 1593 (PNH†; iso K, L ) Malaysia, Sabah, near Sandakan.

Plant (sub)glabrous or hairy. Leaves: $8-15 \mathrm{~cm}$ long. Male flowers: bud $2 \mathrm{~mm}$ diam., open corolla 5-7 mm diam.; petals $2.5-3.5 \mathrm{~mm}$ long.

Distribution - NE India, China, south-east to New Guinea. One distinct variety in Borneo.

Notes - 1. Zanonia indica subsp. orientalis is distributed over a vast area and shows considerable variation in hairiness and size of fruit. Conspicuously hairy specimens, of provenance from a wide area, induced Cogniaux (1881) to recognize a variety with hairy branches, var. pubescens. We found that hairiness usually concerns all parts of the plant, including fruits, and it is variable from (almost) glabrous to densely hairy, although subglabrous plants may still have finely hairy inflorescences and tendrils. Despite that strongly hairy forms (most frequent on limestone in Central Thailand, for instance) may conspicuously differ in appearance from glabrous forms, we cannot see other than a continuous variation.

The same holds true for the size of the fruits: its length generally varies from 6-9 $\mathrm{cm}$, but strikingly small fruits, c. 4 by $2(-2.5) \mathrm{cm}$ seem usual in New Guinea. Very large hairy fruits, c. 10 by $4.5-5 \mathrm{~cm}$, with long-winged seeds, c. 8 by $2 \mathrm{~cm}$, are mentioned for S Yunnan (Chen, 1995), under the variety pubescens. In var. indica of Chinese floras (Chen, 1986, 1995) these dimensions are smaller. We have not seen this material and we do not know whether the large-fruited plants merit a separate status.

2. Sterile material of $Z$. indica may much resemble sterile Alsomitra macrocarpa. The latter generally has longer petioles and a characteristic short-hairy spot in the leaf axil; also, the adhesive pads which may develop at the end of the tendril-branches are larger and more elongate, to $1.3 \mathrm{~cm}$ long (Fig. 2g). Furthermore, the bark of twigs in Alsomitra is not or but finely striate (coarsely striate in Zanonia), and without or with few very small lenticels.

\section{KEY TO THE VARIETIES}

1a. Female flowers larger; ovary $8-10 \mathrm{~mm}$ long; petals $4-5 \mathrm{~mm}$ long. Fruit $4-10 \mathrm{~cm}$ long, pubescent, glabrescent or glabrous; pericarp finely wrinkled or irregularly

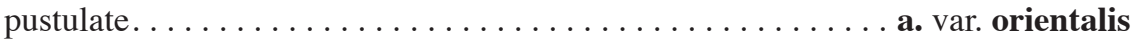

b. Female flowers smaller; ovary c. $5 \mathrm{~mm}$ long; petals c. $3 \mathrm{~mm}$ long. Fruit c. $5 \mathrm{~cm}$ long, glabrous; pericarp smooth or finely regularly pustulate. . b. var. paludosa 


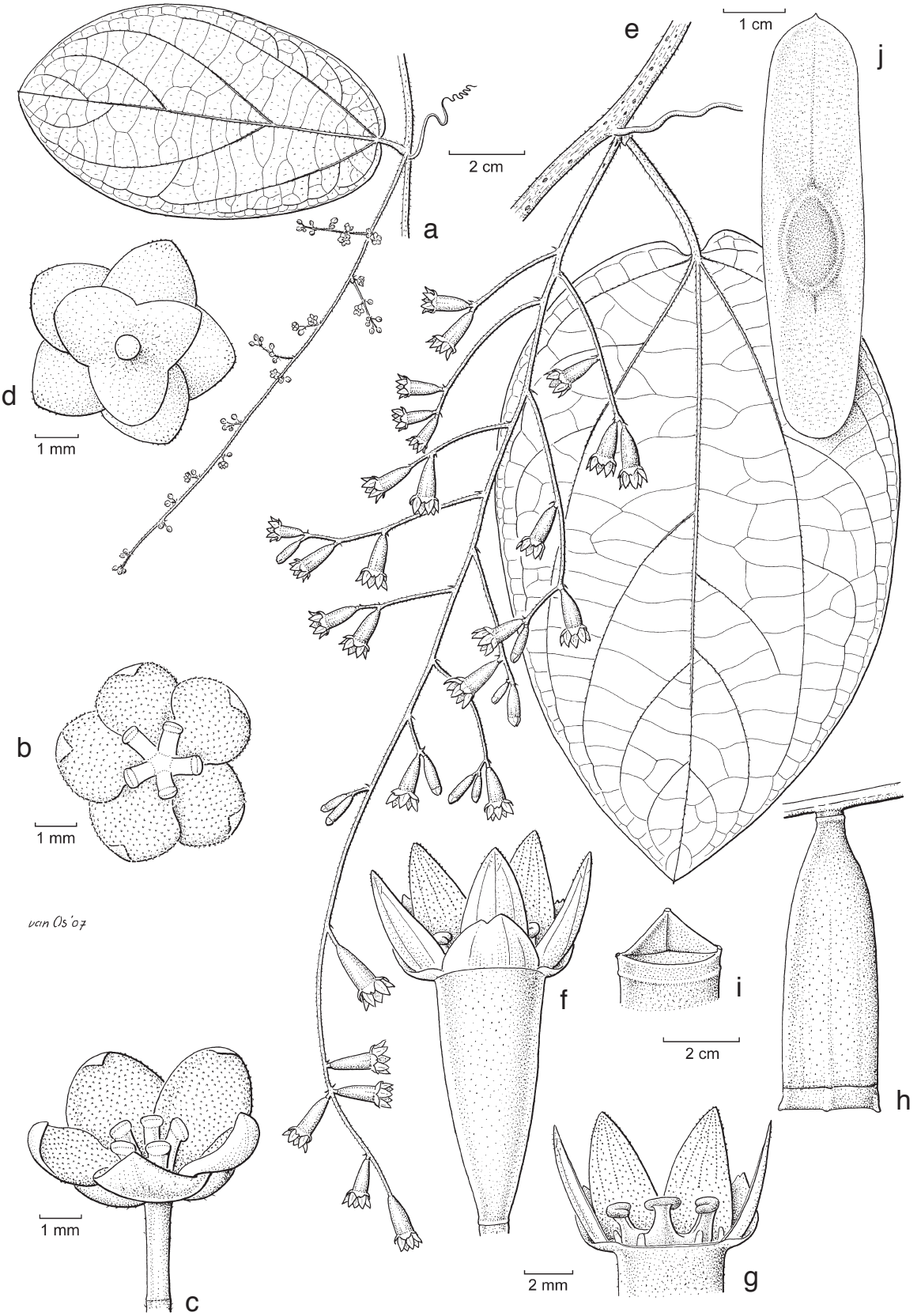

Fig. 1. Zanonia indica L. subsp. orientalis W.J. de Wilde \& Duyfjes var. orientalis. a. Node with male inflorescence; b, c. male flowers; d. ditto, seen from below showing 3-lobed calyx; e. node with female inflorescence; f. female flower; g. apex of female flower, part of perianth removed showing styles and stigmas; h, i. fruit and apex of fruit respectively; j. seed (a: Kerr 2048; b-d: Phonsena, De Wilde \& Duyfjes 5192 (from spirit); e-g: Ramos \& Edaño BS 37397 (type of Alsomitra simplicifolia); $\mathrm{h}-\mathrm{j}$ : Geesink 8384). 

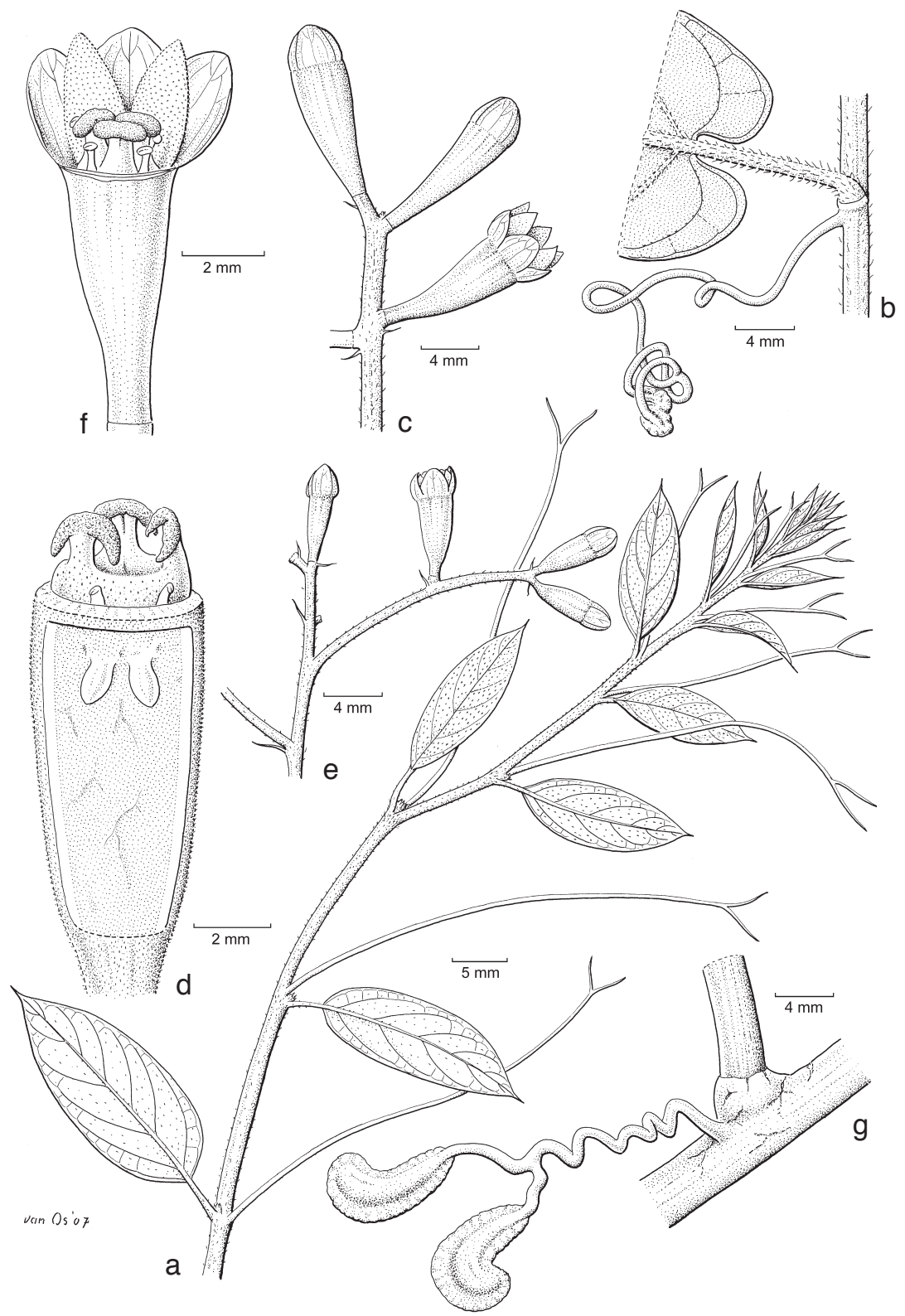

Fig. 2. a-d: Zanonia indica L. subsp. orientalis W.J. de Wilde \& Duyfjes var. orientalis. a. Growing shoot; $b$. node of sterile shoot, note adhesive pads at apex of tendril; c. apex of female inflorescence; d. female flower, perianth removed and ovary longitudinally opened to show position of the ovules. - e, f: Zanonia indica L. subsp. orientalis W.J. de Wilde \& Duyfjes var. paludosa W.J. de Wilde \& Duyfjes. e. Apex of female inflorescence; f. female flower. $-\mathrm{g}$ : Alsomitra macrocarpa (Blume) M. Roem. g. Node with base of petiole and tendril with at apex adhesive pads (a: De Wilde \& Duyfjes 21759; b: Phonsena 3522; c. Korthals s.n. (33); d: De Wilde \& Duyfjes 22125; e, f: Giesen 76 (type); g: McGregor BS 18711). 

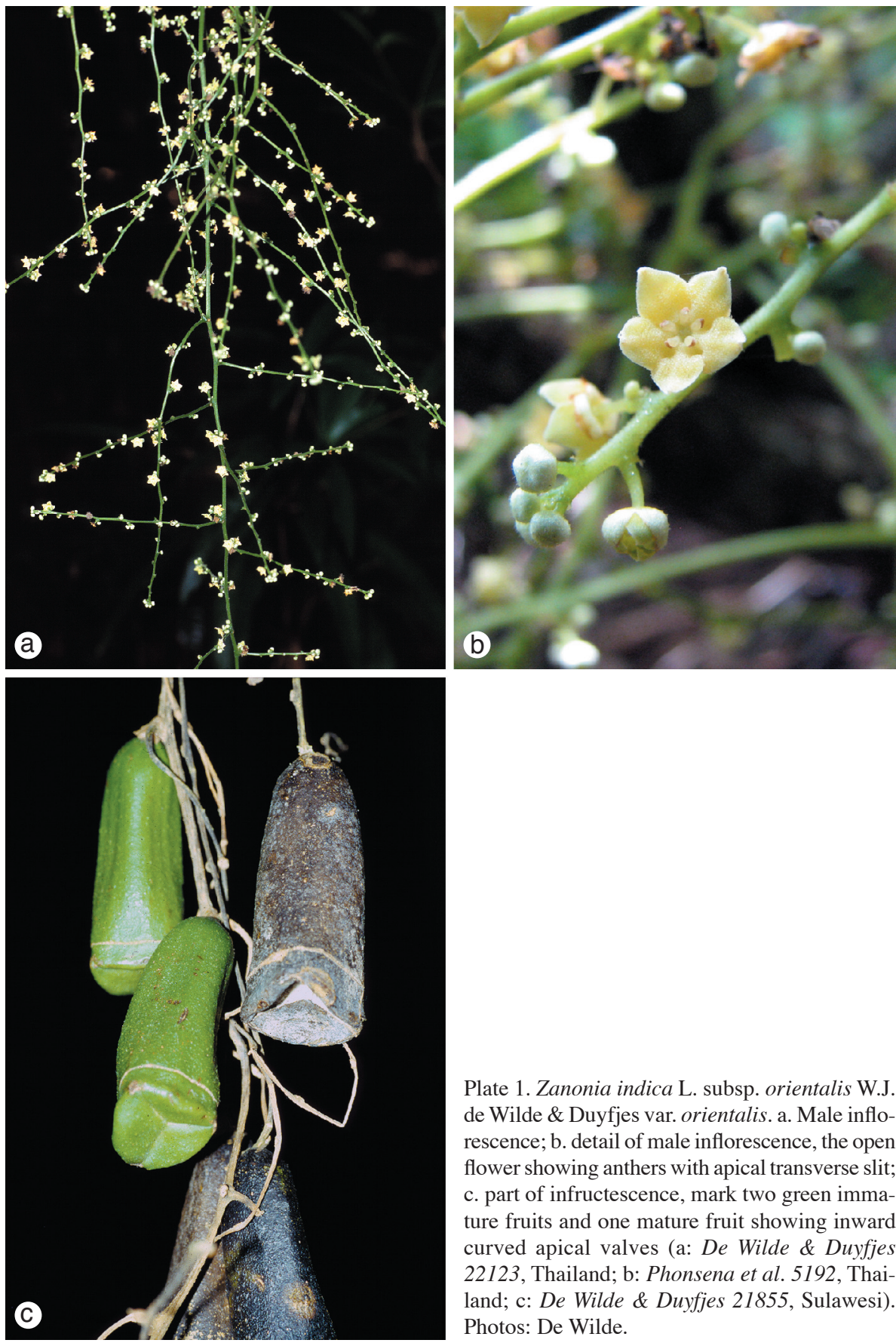

Plate 1. Zanonia indica L. subsp. orientalis W.J. de Wilde \& Duyfjes var. orientalis. a. Male inflorescence; $b$. detail of male inflorescence, the open flower showing anthers with apical transverse slit; c. part of infructescence, mark two green immature fruits and one mature fruit showing inward curved apical valves (a: De Wilde \& Duyfjes 22123, Thailand; b: Phonsena et al. 5192, Thailand; c: De Wilde \& Duyfjes 21855, Sulawesi). Photos: De Wilde. 
Fig. 3. Zanonia indica L. subsp. orientalis W.J. de Wilde \& Duyfjes var. paludosa W.J. de Wilde \& Duyfjes. Twig with infructescences (Anderson $S$ 25559).

a. var. orientalis - Fig. 1, 2a-d;

Plate 1

Climber 6-15 m long, glabrous or hairy. Female flowers: ovary 8-10 $(-12) \mathrm{mm}$ long; sepals $2-3 \mathrm{~mm}$ long; petals $3-5 \mathrm{~mm}$ long. Fruit: $4.5-9$ $(-10) \mathrm{cm}$ long; pericarp irregularly set

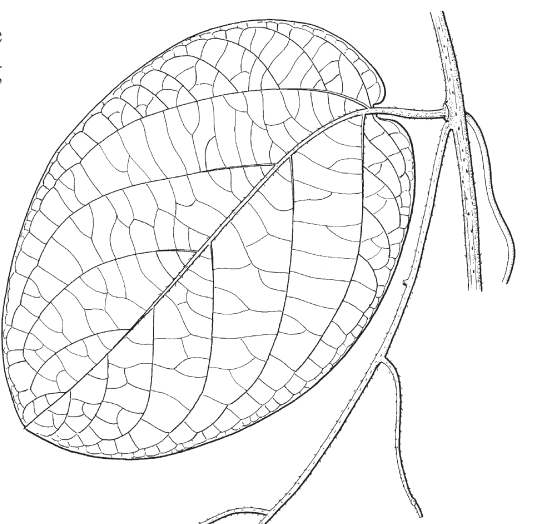
with low wrinkles or pustules.

Distribution - As the subspecies.

b. var. paludosa W.J. de Wilde \& Duyfjes, var. nov. - Fig. 2e-f, 3

A varietate orientali ovario breviore c. $5 \mathrm{~mm}$ longo differt. - Typus: Giesen 76 (L; iso BO, not seen), Kalimantan, Negara River, Barito delta.

Climber 4-6 m long, (sub) glabrous. Female flowers: ovary subglabrous, c. 5 by $1.5-2$ $\mathrm{mm}$; sepals c. $2 \mathrm{~mm}$ long; petals c. $3 \mathrm{~mm}$ long. Fruit: $4.5-5$ by $2 \mathrm{~cm}$, glabrous, smooth or very finely pustulate. Male flowers unknown.

Distribution - Borneo: Sarawak, Rejang delta; S Kalimantan, Barito delta.

Habitat \& Ecology - In riparian forest or transitional forest between mangrove and peat swamp forest at sea level. Flowering and fruiting: December and January.

Note - The only known female flowers (Giesen 76) have conspicuous stamen-like staminodes, as described in note 2 under the genus description.

Specimens examined:

S Kalimantan: Giesen 76 (type). - Sarawak: Anderson S 25559 (A, K, L, SAR, SING). 


\section{ACKNOWLEDGEMENTS}

We feel grateful to Dr. Kongkanda Chayamarit and the staff of BKF (Bangkok) facilitating us to see and collect Zanonia in the wild. We also like to thank Phongsak Phonsena for his enthusiastic and keen collaboration of our Cucurbitaceae project. Herbarium collections from A, AAU, BK, BKF, BM, BO, BRI, E, K, KEP, L, P, and SING, were studied for the present treatment of Zanonia. As usual J.F. Veldkamp (Leiden) kindly provided the translations into Latin of the diagnoses of the new taxa, Jan van Os (Leiden) prepared the beautiful and informative drawings, Ben Kieft (Leiden) scanned in the drawings and edited the photos for publication, and Luc Willemse (Leiden) helped with the realization of the identification list, using BRAHMS.

\section{REFERENCES}

Adanson, M. 1763. Familles des plantes 2: 139, 589. Vincent, Paris.

Backer, C.A. 1964. Cucurbitaceae. In: C.A. Backer \& R.C. Bakhuizen van den Brink Jr., Flora of Java 1: 292-307. Noordhoff, Groningen.

Bentham, G. \& J.D. Hooker. 1867. Genera Plantarum 1: 816-841. Reeve \& Co., London.

Chakravarty, H.L. 1959. Monograph on Indian Cucurbitaceae. Rec. Bot. Surv. India 17: 1-234.

Chakravarty, H.L. 1982. Cucurbitaceae. Fascicles of Flora of India 11: 1-136.

Chen, S. K. 1986. Zanonia. In: A.M. Lu \& S.K. Chen (eds.), Fl. Reipubl. Popularis Sin. 73: 129-130. Science Press, Beijing.

Chen, S.K. 1995. Zanonia. In: C.Y Wu, C. Chen \& S.K Chen (eds.), Flora Yunnanica 6: 297. Science Press, Beijing.

Clarke, C.B. 1879. Cucurbitaceae. In: J.D. Hooker, Flora of British India 2: 604-635. Reeve \& Co., London.

Cogniaux, C.A. 1881. Cucurbitaceae. In: A. \& C. de Candolle, Monographiae Phanerogamarum Prodromi 3: 325-951.

Cogniaux, C.A. 1916. Cucurbitaceae-Fevilleae et Melothrieae. In: A. Engler, Pflanzenreich 66, iv.275.1: 1-277. Engelmann, Leipzig.

Gagnepain, F. 1921. Cucurbitacées. Flore Génerale de l'Indo-Chine 2: 1030-1095. Masson \& Cie., Paris.

Grierson, A.J.C. \& D.G. Long. 1991. Flora of Bhutan 2: 246-270. Royal Botanic Garden, Edinburgh.

Hô, P.H. 1991. Cucurbitaceae. In: An illustrated Flora of Vietnam 1, 2: 711-728, f. 1974-2020. Mekong printing, Santa Ana.

Jeffrey, C. 1980. Further notes on Cucurbitaceae V. The Cucurbitaceae of the Indian subcontinent. Kew Bull. 34: 789-809.

Keraudren-Aymonin, M. 1975. Cucurbitacées. In: A. Aubréville \& J.-F. Leroy (eds.), Flore du Cambodge, du Laos et du Viêt-nam 15: 1-114. Mus. Nat. Hist. Nat., Paris.

Linnaeus, C. 1753. Species Plantarum ed. 1, 2: 1028. Stockholm.

Linnaeus, C. 1754. Species Plantarum ed. 5: 454. Stockholm.

Linnaeus, C. 1759. Systema naturae ed. 10: 1292. Stockholm.

Linnaeus, C. 1763. Species Plantarum ed. 2: 1457. Stockholm.

Manilal, K.S. 2003. Van Rheede's Hortus Malabaricus. English edition with annotations and modern botanical nomenclature 8: 166-172. University of Kerala.

Merrill, E.D. 1922a. New or noteworthy Bornean plants. (Part 1). J. Straits Branch Roy. Asiat. Soc. 85: $170-171$.

Merrill, E.D. 1922b. Noteworthy Philippine plants. Philipp. J. Sci. 20: 470-471.

Miquel, F.A.G. 1856. Flora Indiae Batavae 1, 1: 652-683. Van der Post, Amsterdam.

Ridley, H.N. 1920. New Malayan plants. J. Bot. 58: 147-149.

Van Rheede tot Draakestein, H.A. 1688. Hortus Malabaricus 8: 91-93, t. 47-48. Abraham Poot, Amsterdam.

Wight, R. 1850. Illustrations of Indian botany 2: 24-33, pl. 103-105* or 121. P.R. Hunt, American Mission Press, Madras. 


\title{
IDENTIFICATION LIST
}

\author{
1 = Zanonia indica subsp. indica \\ $2 \mathrm{a}=$ Zanonia indica subsp. orientalis var. orientalis \\ $2 \mathrm{~b}=$ Zanonia indica subsp. orientalis var. paludosa
}

Anderson S 25559: 2b.

Beccari 4020: 2a - Bell 7836: 1; 7936: 1 - Blume 189: 2a - Boulanger 1384: 2a - Brass 29354: 2a - Buwalda 5210: 2a.

Coode NGF 32721: 2a - Corner SF 29980: 2a - Cramer 4545: 1 - Curtis 3464: 2a.

d'Alleizette 2688: 2a - Dalzell 1865: 1 - De Wilde 21698: 2a; 21759: 2a; 21855: 2a; 22123: 2a; 22125: 2a; SAN 141910: 2a - Docters van Leeuwen-Reynvaan 925: $2 \mathrm{a}$.

Elmer 9645: 2a.

Geesink 8384: 2a - Giesen 76: $2 \mathrm{~b}$ - Griffith 2521: 2a.

Hartley TGH 10037: 2a - Haviland 1867: 2a; 2328: 2a - Hose 84: $2 \mathrm{a}$.

Keenan 1836: 2a - Kerr 2048: 2a; 20645: 2a - King's collector 7362: 2a; 8013: 2a - Koorders 23568: 2a; 27506: 2a.

Ledermann 7286: 2a - Lim SAN 144702: 2a.

Marcan 726: 2a - Middleton 3090: 2a - Motley 920: 2a.

Nair 4845: 2a; 78302: 1.

Phonsena 2877: 2a; 3522: 2a; 4589: 2a; 5192: 2a; 5209: 2a - Pierre 394: 2a; 1279: 2a - Postar SAN 144651: $2 \mathrm{a}$.

Ramos 1593: 2a; BS 37397: 2a; BS 43946: 2a.

Schlechter 18919: 2a - Scortechini 482: 2a - Streimann NGF 47711: 2a.

Thwaites CP 1628: 1 - Toroes 5476: 2a.

Versteegh BW 4905: 2a.

Walker 1455: 1 - Wight 1125: 1 . 